\title{
EVALUATION OF THREE SUGARCANE VARIETIES GROWN UNDER DIFFERENT NUMBER OF IRRIGATIONS
}

\author{
AHMED, Z. A., A.M. AHMED and K.S. EL-SOGHIER \\ Sugar Crops Res. Inst. , ARC, Giza, Egypt.
}

(Manuscript received 4 June 2013)

\begin{abstract}
The present study was carried out at El-Mattana Agricultural Research Station, (latitude of $25.17^{\circ} \mathrm{N}$ and longitude $32.33^{\circ} \mathrm{E}$ ), Luxor Governorate, Upper Egypt in 2008/2009 and 2009/2010 growing seasons to evaluate the performance of three sugarcane varieties F. 160, Phil. 8013 and the commercial variety G.T.54-9) grown under different number of irrigations to obtain maximum cane and sugar yields/Fed. A split-plot experimental design with four replications was used in this work, where the main plots were assigned for number of irrigations, while sugarcane varieties were distributed in the sub-plots. The results showed that increasing the number of irrigations from 14 to 18 and 22 increased considerably stalk height, number of millable canes $/ \mathrm{m}^{2}$, reducing sugars, cane and sugar yields/Fed. Meanwhile, sucrose, purity and sugar recovery percentages were insignificantly influenced by irrigation number. The tested sugarcane varieties differed significantly in stalk height, number of millable canes $/ \mathrm{m}^{2}$, reducing sugars, juice purity \%, cane and sugar yields. Commercial variety G.T. 54-9 recorded the highest values of stalk height and number of millable canes $/ \mathrm{m}^{2}$ (in both seasons) as well as purity \%, cane and sugar yields (in the $2^{\text {nd }}$ season). Sugarcane Phil. 8013 variety attained the highest cane and sugar yields, in the $1^{\text {st }}$ season. Sugarcane F. 160 variety had the shortest stalks, the lowest number of millable canes $/ \mathrm{m}^{2}$, juice purity\%, cane and sugar yields, but it recorded the highest reducing sugars \%, compared with the other two varieties. It could be concluded that under the conditions of the present work, growing either G.T.54-9 or Phil.8013 with the application of 22 irrigations can be recommended to obtain the highest cane and sugar yields/fed.
\end{abstract}

\section{INTRODUCTION}

Irrigation is one of the major factors affecting germination, tillering, boom stage, sugar synthesis and accumulation and hence cane and sugar yields. In this respect, sugarcane is adversely affected by water logging which from some problems including leaching of water by percolation and loss available nutrients beyond root zone, lodging, pests and diseases and harvesting difficulties. In addition, excessive application of water causes inadequate soil aeration and low water potential. Van Dillewijn (1952) mentioned that, for sugarcane, to constitute one particle of dry matter, it absorb 250 particle of water, and that water is an essential factor for turgidity of leaf cells, lengthening of stalk cells as well as photosynthesis process. He 
added that water is the most important feed quantitatively for sugarcane. Humbert (1968) stated that water is the key for growth, ripening and conversion of reducing sugars (glucose and fructose) into sucrose.

As for irrigations number effect, Shahin et al. (1989) elucidated that plant cane given 31, 30, 28 and 27 irrigations time significantly increased stalk yield by $38.77 \%, 33.25 \%, 30.71 \%$ and $28.7 \%$, respectively, as compared with those received 17 irrigations. They added that irrigated plant cane 31, 30, 28 and 27 irrigations led to a significant increase in sugar yield by $28.32 \%, 21.87 \%, 23.51 \%$ and $21.61 \%$, respectively as compared with those given 17 irrigations. Moreover, there was a very high significant but negative association between number of irrigations and sucrose $\%$ and recovery\% in sugarcane juice. Said Rahman et al. (1991) evaluated twelve lines and varieties of sugarcane under three irrigation intervals (1, 2 and 3-week). They found that the highest plant height was obtained with 1-week intervals. El-Shafai (1996) showed that the $2^{\text {nd }}$ regimes significantly increased number of sugarcane plants $/ \mathrm{m}^{2}$, while stalk height was not significantly affected. Irrigation at shorter intervals of the $2^{\text {nd }}$ regime increased stalk diameter and prolonging irrigation intervals in the third regime increased TSS\%. He added that supplying sugarcane with 28 irrigations insignificantly increased number of millable cane/fed and sugar yield/fed. Maher (2003) stated that application of 19 or 22 irrigations recorded the highest cane yield and sugar yield compared with 16 irrigations. He added that the difference between the studied irrigation treatments was not significant in their effect on sucrose and purity percentages.

The role of sugarcane variety is considered the corner stone or the main factor in governing the expected sugar yield. It is well known that sugarcane varieties are widely different in their potentiality with regard to cane and sugar yields. In this connection, Azzazy, et al. (2005) found that cane varieties G.T.54-9, Phil. 8013, G.9521, G.99-165, G.98-28 and G.95-19 differed significantly in their stalk height, sucrose $\%$ and sugar recovery $\%$ as well as cane and sugar yields. Ahmed and El-Shafai (2007) found that sugarcane variety G.T.54-9 surpassed Phil. 8013 significantly in cane stalk height, number of millable cane $/ \mathrm{m}^{2}$, sucrose $\%$, sugar recovery $\%$, cane and sugar yields. Ismail et al. (2008) showed that the tested sugarcane varieties significantly differed in all the studied traits except purity\%, cane and sugar yields. The commercial cv. G.T. 54-9 showed superiority in stalk length, purity, sugar recovery percentage and sugar yield/fed. El-Sogheir and Abd El Fattah (2009) found that the commercial sugarcane variety G.T. 54-9 recorded higher values of stalk length, cane and sugar yields compared with other tested varieties (Phil. 8013, G. 9828 and G. 99-165). Ahmed et al. (2011) found that the promising sugarcane variety 
G.95-21 significantly surpassed the other ones G. 95-19 in number of millable canes/fed, millable stalk and cane yield/fed. Mohamed, et al. (2012) found that sugarcane cvs. G.T.54-9, G.84-47 and G.2001-79 differed significantly in their stalk height, sucrose $\%$, reducing sugars and sugar recovery\% as well as cane and sugar yields.

The aim of the present work was to find out the optimum irrigation times required for the tested sugarcane varieties to obtain the ideal cane and sugar yields/fed.

\section{MATERALS AND METHODS}

Two field experiments was conducted at El-Mattana Agricultural Research Station, (latitude of $25.17^{\circ} \mathrm{N}$ and longitude $32.33^{\circ} \mathrm{E}$ ), Luxor Governorate, in $2008 / 2009$ and 2009/2010 growing seasons to investigate the performance of three sugarcane varieties (F.160, Phil.8013 in addition to the prevailing variety G.T.54-9) grown under different number of irrigations $(14,18$, and 22 irrigations, i.e. average irrigation intervals of 22, 17 and 14 days). Sugarcane varieties were planted on $15^{\text {th }}$ March and harvested 12 months later in both seasons. Water was applied in furrows of $60-\mathrm{m}$ long to flow with slope, using aluminum perforated pipes of 6 -inch diameter, 6-m length and a spacing of $0.9 \mathrm{~m}$ between orifices (the distance between furrows) along the pipes with a flow rate of $1.5 \mathrm{l} / \mathrm{h} /$ orifice. A centrifugal diesel pumping unit of $5.1 / 4.1 \mathrm{Hp} / \mathrm{kw}, 1450 \mathrm{rpm}$ with a maximum discharge of $90 \mathrm{~m}^{3} / \mathrm{h}$ was used, where a water flow meter was connected to it to determine irrigation water applied, $\mathrm{m}^{3} / \mathrm{fed}$.

A split plot design in four replications was used, where the main plots were assigned for number of irrigations, while sugarcane varieties were distributed in the sub-plots. Sub-plot area was $31.5 \mathrm{~m}^{2}$ (comprised 5 ridges of $0.9 \mathrm{~m}$ apart and 7-m long). The physical and chemical properies of the experimental site showed that the upper $30 \mathrm{~cm}$ of the soil was clay loam including $40.4 \%$ sand, $14.4 \%$ silt and 45.2 clay containing 79.0,10.7, $198 \mathrm{ppm} \mathrm{N}, \mathrm{P}_{2} \mathrm{O}_{5}, \mathrm{~K}_{2} \mathrm{O}$, respectively and $\mathrm{pH}$ of 7.6. The other agricultural operations were practiced as recommended by the Sugar Crops Research Institute, Agricultural Research Center.

Worth to mention that irrigation water was applied using a "Developed Surface Irrigation System" through perforated pipes, preceded by precise land levelling using LASER grading technique. This system has been proved feasible technically and economically. It does not require special skills for operation adding to saving water and time of irrigation as well as its positive effect on crop yield through the uniformity of wet soil profile. It also decreases time of irrigation and increases 
water use efficiency compared with the traditional land levelling and irrigation in a long-term crop as sugar cane.

Table 1. Amounts of water $\left(\mathrm{m}^{3} / \mathrm{fed}\right)$ applied to sugarcane under the three irrigation treatments throughout the two growing seasons

\begin{tabular}{|c|c|c|c|c|c|c|}
\hline \multirow{3}{*}{$\begin{array}{c}\text { NO. of Irrig. } \\
\text { Date }\end{array}$} & \multicolumn{3}{|c|}{$2008 / 2009$ season } & \multicolumn{3}{|c|}{$2009 / 2010$ season } \\
\hline & \multicolumn{6}{|c|}{ Number of irrigation } \\
\hline & 14 & 18 & 22 & 14 & 18 & 22 \\
\hline 15 March & 844 & 866 & 843 & 850 & 862 & 837 \\
\hline 30 March & 452 & 472 & 458 & 450 & 448 & 426 \\
\hline 15 April & - & - & 538 & - & - & 555 \\
\hline 30 April & 788 & 746 & 635 & 735 & 766 & 607 \\
\hline 15 May & 622 & 655 & 665 & 630 & 643 & 670 \\
\hline 30 May & - & - & 645 & - & - & 617 \\
\hline 15 June & 780 & 762 & 635 & 762 & 733 & 672 \\
\hline 30 June & 693 & 681 & 708 & 662 & 671 & 707 \\
\hline 15 July & - & 755 & 747 & - & 730 & 751 \\
\hline 30 July & 733 & 637 & 626 & 710 & 625 & 601 \\
\hline 15 August & 513 & 568 & 508 & 618 & 535 & 567 \\
\hline 30 August & - & 480 & 495 & - & 492 & 418 \\
\hline 15 September & 596 & 416 & 445 & 583 & 478 & 440 \\
\hline 30 September & - & 460 & 436 & - & 433 & 407 \\
\hline 15 October & 577 & - & 405 & 563 & - & 385 \\
\hline 30 October & - & 432 & 373 & - & 416 & 367 \\
\hline 15 November & 480 & 390 & 326 & 456 & 388 & 301 \\
\hline 30 November & - & - & 310 & - & - & 295 \\
\hline 15 December & 372 & 433 & 306 & 385 & 410 & 300 \\
\hline 30 December & \multicolumn{6}{|c|}{ Winter withholding } \\
\hline 15 January & 370 & 392 & 345 & 350 & 388 & 371 \\
\hline 30 January & - & 280 & 281 & - & 296 & 272 \\
\hline 15 February & 326 & 277 & 262 & 319 & 270 & 260 \\
\hline Water ( $\mathrm{m}^{3} / \mathrm{fed} /$ season $)$ & 8146 & 9702 & 10992 & 8073 & 9584 & 10430 \\
\hline
\end{tabular}

\section{The recorded data:}

The following data were recorded at harvest:

1. Number of millable canes $/ \mathrm{m}^{2}$ was count.

2. Millable cane height $(\mathrm{cm})$, which was measured from soil level up to the top visible dewlap. A sample of 25 millable stalks from each treatment was collected at harvest, cleaned and crushed to determine Brix sucrose and Reducing sugars while, the there parameters were calculated as follows:

3. Sucrose percentage was determined using Saccharemeter according to A.O.A.C. (1995). 
4. Reducing sugars $/ 100 \mathrm{~cm}^{3}$ juice was determined according to (Anonymous, 1981) and carried out in the Chemical Control Lab., the Egyptian Co. for Sugar and Integrated Industries.

5. Juice purity percentage was calculated according to the following equation:

Purity $\%=$ sucrose $\%$ x $100 /$ Brix $\%$.

Where: brix \% (total soluble solids, \%) in juice, which was determined using Brix Hydrometer.

6. Sugar recovery percentage was determined according to the formula described by Yadav and Sharma (1980) as follows:

Sugar recovery $\%=[$ sucrose $\%-0.4$ (brix - sucrose) $] 0.73$.

7. Cane yield: millable canes of three guarded rows of all sub plots were harvested, topped, cleaned, weighed to determine cane yield (tons/fed).

8. Sugar yield (tons/fed) was estimated as follows: Sugar yield (tons/fed) = cane yield (tons/fed) $x$ sugar recovery percentage.

All the recorded data were statistically analyzed according to the method of Snedecor and Cochran (1981). Treatment means were compared using last significance differences (L SD) at 5\% level of probability.

\section{RESULTS AND DISCUSSION}

\section{Number of millable canes $/ \mathrm{m}^{2}$ :}

Data in Table 2 pointed a significant increase in the number of millable canes $/ \mathrm{m}^{2}$ amounted 0.90 and 1.72 stalks $/ \mathrm{m}^{2}$, in the $1^{\text {st }}$ season and 0.85 and 2.86 , in the $2^{\text {nd }}$ one, as a result of increasing the number of irrigations given to sugarcane from 18 to 22 , as compared to that supplied with 14 irrigations. These results may be due to the fact that water is an essential factor for the turgidity of leaf cells, lengthening of stalk cells as well as photosynthesis process, as mentioned by Van Dillewijn (1952), who mentioned that water is the most important food quantitatively for sugarcane. Moreover, Humbert (1968) stated that light frequent irrigations are preferable for young aged canes in the formative phase (the $1^{\text {st }}$ four months of cane plant age). These results are in agreement with that found by El-Shafai (1996), who cleared that the highest number of sugarcane plants $/ \mathrm{m}^{2}$ was produced by supplying sugarcane with 28 irrigations, compared with 23 and/or 17 irrigations.

Sugarcane varieties differed significantly in the number of millable canes $/ \mathrm{m}^{2}$ in the $1^{\text {st }}$ season. These results are in accordance with those reported by Ahmed and ElShafai (2007) and Ahmed, et al. (2011). Data in Table (2) noticed that G.T. 54-9 variety surpassed the other two varieties by 4.06 and 0.34 canes, in the $1^{\text {st }}$ season, 
and 2.96 and 0.70 canes, in the $2^{\text {nd }}$ ones. Furthermore, F. 160 variety had the lowest tellering ability otherwise, G.T. 54-9 characterized with the highest tellering ability among the tested cane varieties. The variance among varieties in this trait may be due to their gene make-up.

The interactions between varieties and number of irrigation times had insignificant influence on the number of millable canes $/ \mathrm{m}^{2}$ in both seasons.

Table 2. Effect of number of irrigation times on number of millable canes $/ \mathrm{m}^{2}$ of the three sugarcane varieties in 2008/2009 and 2009/2010 seasons.

\begin{tabular}{|c|c|c|c|c|c|c|c|c|}
\hline \multirow{2}{*}{$\begin{array}{l}\text { Variety } \\
\text { Irrigatio } \\
\text { n No. }\end{array}$} & \multicolumn{4}{|c|}{$2008 / 2009$ season } & \multicolumn{4}{|c|}{$2009 / 2010$ season } \\
\hline & G.T. 54-9 & F. 160 & $\begin{array}{l}\text { Phil. } \\
8013\end{array}$ & Mean & G.T. 54-9 & F. 160 & Phil. 8013 & Mean \\
\hline 14 & 12.23 & 8.02 & 12.00 & 10.75 & 12.34 & 8.80 & 8.47 & 9.87 \\
\hline 18 & 13.07 & 9.02 & 12.87 & 11.65 & 10.25 & 9.35 & 12.56 & 10.72 \\
\hline 22 & 13.97 & 10.06 & 13.39 & 12.47 & 14.39 & 9.95 & 13.85 & 12.73 \\
\hline Mean & 13.09 & 9.03 & 12.75 & 11.62 & 12.33 & 9.37 & 11.63 & 11.11 \\
\hline
\end{tabular}

LSD at 0.05 level for:

Number of irrigation $(A)$

0.37

1.49

Cane varieties (B)

0.90

N.S

(A) $\times(B)$

N.S

N.S

\section{Millable canes height:}

Data in Table 3 showed that increasing the number of irrigations from 14 to 18 and 22 increased considerably and gradually millable canes height of sugarcane by 15.34 and $32.89 \mathrm{~cm}$, in the $1^{\text {st }}$ season, and by 14.78 and $43.78 \mathrm{~cm}$, in the $2^{\text {nd }}$ ones, respectively. These results may be due to the fact that water is an essential factor for the turgidity of leaf cells, lengthening of stalk cells as well as photosynthesis process, as mentioned by Van Dillewijn (1952). These results are in line with those reported by Said Rahman et al. (1991), who pointed out that the highest plant height was obtained with 1-week, compared with 2 and/or 3-week intervals.

The results in the same Table pointed to a significant variance between the three sugarcane varieties in stalk height in both seasons. This result is in agreement with those found by Ismail et al. (2008) and El-Sogheir and Abd El Fattah (2009). The commercial variety G.T. 54-9 surpassed Phil. 8013 and F. 160 varieties in height by 7.67 and $20.78 \mathrm{~cm}$, in the $1^{\text {st }}$ season, corresponding to 2.89 and $13.22 \mathrm{~cm}$, in the $2^{\text {nd }}$ one, respectively. Meanwhile, F.160 had the shortest stalks. In the Moreover, the 
difference between G.T. 54-9 and Phil. 8013 in this trait was insignificant in the $2^{\text {nd }}$ season. The differences among varieties in stalk height could be attributed to their genetic structure.

There was insignificant variance on stalk height due to the interactions between varieties and number of irrigations, in both seasons.

Table 3. Effect of number of irrigation times on stalk height $(\mathrm{cm})$ of the three sugarcane varieties in 2008/2009 and 2009/2010 seasons.

\begin{tabular}{|c|c|c|c|c|c|c|c|c|}
\hline \multirow{2}{*}{$\begin{array}{c}\text { Irrigation } \\
\text { No. }\end{array}$} & \multicolumn{4}{|c|}{ 2008/2009 season } & \multicolumn{4}{|c|}{ 2009/2010 season } \\
\cline { 2 - 9 } & G.T. 54-9 & F. 160 & Phil. 8013 & Mean & G.T. 54-9 & F. 160 & Phil. 8013 & Mean \\
\hline 14 & 214.33 & 192.67 & 208.67 & 205.22 & 226.67 & 215.67 & 220.33 & 220.89 \\
\hline 18 & 227.33 & 210.00 & 224.33 & 220.56 & 240.00 & 229.00 & 238.00 & 235.67 \\
\hline 22 & 250.67 & 227.33 & 236.33 & 238.11 & 270.67 & 253.00 & 270.33 & 264.67 \\
\hline Mean & 230.78 & 210.00 & 223.11 & 221.30 & 245.78 & 232.56 & 242.89 & 240.41 \\
\hline
\end{tabular}

LSD at 0.05 level for:

Number of irrigation $(A)$

\section{Sucrose percentage:}

Data in Table 4 indicated that sucrose percentage was insignificantly affected by number of irrigations, in the $1^{\text {st }}$ and $2^{\text {nd }}$ seasons. This result is in agreement with that reported by Maher (2003). Moreover, insignificant difference among the tested sugarcane varieties in sucrose percentage, in both seasons have been detected (Table 4).

Table 4. Effect of number of irrigations on sucrose percentage of the three sugarcane varieties in 2008/2009 and 2009/2010 seasons.

\begin{tabular}{|c|c|c|c|c|c|c|c|c|}
\hline \multirow{2}{*}{$\begin{array}{l}\text { Variety } \\
\text { Irrigation } \\
\text { No. }\end{array}$} & \multicolumn{4}{|c|}{ 2008/2009 season } & \multicolumn{4}{c|}{ 2009/2010 season } \\
\hline & G.T. 54-9 & F. 160 & Phil. 8013 & Mean & G.T. 54-9 & F. 160 & Phil. 8013 & Mean \\
\hline 14 & 16.27 & 16.36 & 17.45 & 16.69 & 16.69 & 14.75 & 14.43 & 15.29 \\
\hline 18 & 16.60 & 16.90 & 16.75 & 16.75 & 13.50 & 14.65 & 15.71 & 14.62 \\
\hline 22 & 17.41 & 16.04 & 17.07 & 16.84 & 15.75 & 14.41 & 15.49 & 15.22 \\
\hline Mean & 16.76 & 16.43 & 17.09 & 16.76 & 15.31 & 14.60 & 15.21 & 15.04 \\
\hline
\end{tabular}

L.S.D at 0.05 level for:

Number of irrigation $(A)$ 
Sucrose percentage was significantly influenced by the interaction between varieties and number of irrigations in the $2^{\text {nd }}$ season only. Under irrigation for 22 time, and both seasons G.T. 54-9 exhibited the highest sucrose percentage followed by Phil. 8013 and F. 160 in descanting order.

\section{Reducing sugars percentage:}

Data in Table 5 manifested that reducing sugars \% tended to increase as the number of irrigations were increased from 14 up to 22 . However, the difference in this trait reached the level of significance in the $1^{\text {st }}$ season only. These results may be due to the fact that the availability of water (increasing number of irrigations) enhances plant growth, where reducing sugars (glucose and fructose) are required, while the shortage of water (decreasing number of irrigations) pushes cane plants towards ripening, i.e. accumulate these mono-saccharides into di-saccharide "sucrose" in cane stalks.

The evaluated sugarcane varieties varied significantly in reducing sugars $\%$, in the $1^{\text {st }}$ and $2^{\text {nd }}$ seasons. It could be noticed that F.160 variety recorded that highest values of this trait compared with the other ones. In addition, the variance between G.T.54-9 and Phil. 8013 varieties in reducing sugars \% was not significant in both seasons. The variance among varieties in this trait may be due to their gene structure. These findings are in accordance with those found by Ismail et al. (2008) and Mohamed, et al. (2012).

Table 5. Effect of number of irrigation times on reducing sugars percentage

of the three sugarcane varieties in 2008/2009 and 2009/2010 seasons.

\begin{tabular}{|c|c|c|c|c|c|c|c|c|}
\hline \multirow{2}{*}{ Variety } & \multicolumn{5}{|c|}{$2008 / 2009$ season } & \multicolumn{4}{|c|}{$2009 / 2010$ season } \\
\cline { 2 - 9 } Irrigation & G.T. 54-9 & F. 160 & Phil. 8013 & Mean & G.T. 54-9 & F. 160 & Phil. 8013 & Mean \\
No. & & & & & & & & \\
\hline 14 & 0.67 & 0.57 & 0.65 & 0.63 & 0.28 & 0.31 & 0.35 & 0.31 \\
\hline 18 & 0.60 & 0.75 & 0.62 & 0.66 & 0.29 & 0.37 & 0.30 & 0.32 \\
\hline 22 & 0.84 & 0.87 & 0.57 & 0.76 & 0.32 & 0.43 & 0.38 & 0.37 \\
\hline Mean & 0.70 & 0.73 & 0.61 & 0.68 & 0.29 & 0.37 & 0.34 & 0.33 \\
\hline
\end{tabular}

L.S.D at 0.05 level for:

Number of irrigation $(A)$

0.07

N.S

Cane varieties (B)

0.08

0.07

(A) $\times(B)$

0.15

N.S

The interaction between number of irrigations and the tested sugarcane cane varieties affected significantly reducing sugars $\%$, in the $1^{\text {st }}$ season. The difference between G.T. 54-9 and Phil. 8013 varieties in reducing sugars \% was significant when 
they were irrigated 22 times. On the contrary, the difference between the two varieties was insignificant when they received 14 irrigations.

\section{Juice purity percentage:}

Data in Table 6 showed that juice purity $\%$ was insignificantly affected by the various number of irrigations in the $1^{\text {st }}$ and $2^{\text {nd }}$ seasons.

Also data in the same table showed that a significant difference was found among the evaluated sugarcane varieties in juice purity percentage in the $2^{\text {nd }}$ season only. The highest mean value of this trait was recorded by the commercial sugarcane variety G.T. 54-9, while the lowest was of F.160 variety. These results are probably attributed to the content of both sucrose and reducing sugars in cane juice, where the higher the sucrose percentage and the lower the reducing sugars recorded by the studied cane varieties (Tables 4 and 5 ). The variance among varieties in this trait may be due to their gene structure. These results are in agreement with those reported by Ismail et al. (2008) and Mohamed, et al. (2012).

Juice purity \% was significantly affected the interaction between number of irrigation times and cane varieties, in the $1^{\text {st }}$ and $2^{\text {nd }}$ seasons. In the $1^{\text {st }}$ one, G.T. 54-9 and Phil.8013 varieties differed significantly in purity percentage when they were irrigated 18 times. However, insignificant difference between the two varieties was found in case of applying 14 irrigations. The same trend was observed in the $2^{\text {nd }}$ season.

Table 6. Effect of number of irrigations on juice purity percentage of the three sugarcane varieties in 2008/2009 and 2009/2010 seasons.

\begin{tabular}{|c|c|c|c|c|c|c|c|c|}
\hline \multirow{2}{*}{$\begin{array}{c}\text { Variety } \\
\text { Irrigation } \\
\text { No. }\end{array}$} & \multicolumn{4}{|c|}{ 2008/2009 season } & \multicolumn{3}{c|}{ 2009/2010 season } \\
\hline 14 & 87.55 & 85.47 & 89.22 & 87.41 & 85.53 & 80.48 & 76.08 & 80.70 \\
\hline 18 & 86.47 & 88.33 & 89.93 & 88.24 & 83.10 & 79.62 & 81.27 & 81.33 \\
\hline 22 & 87.71 & 89.13 & 87.07 & 87.97 & 82.91 & 75.85 & 82.35 & 80.37 \\
\hline Mean & 87.24 & 87.64 & 88.74 & 87.87 & 83.84 & 78.65 & 79.90 & 80.80 \\
\hline
\end{tabular}

L.S.D at 0.05 level for:

Number of irrigation $(A)$

\section{Sugar recovery percentage:}

Data in Table 7 revealed that sugar recovery percentage was insignificantly influenced by both irrigations number, and cane varieties or their interactions, in the $1^{\text {st }}$ and $2^{\text {nd }}$ seasons. 
Table 7. Effect of number of irrigations on sugar recovery percentage of the three sugarcane varieties in 2008/2009 and 2009/2010 seasons.

\begin{tabular}{|c|c|c|c|c|c|c|c|c|}
\hline \multirow{2}{*}{$\begin{array}{l}\text { Variety } \\
\text { Irrigation } \\
\text { No. }\end{array}$} & \multicolumn{4}{|c|}{$2008 / 2009$ season } & \multicolumn{4}{|c|}{$2009 / 2010$ season } \\
\hline & G.T.54-9 & F.160 & Phil.8013 & Mean & G.T.54-9 & F.160 & Phil.8013 & Mean \\
\hline 14 & 13.70 & 13.39 & 14.83 & 13.97 & 14.01 & 10.62 & 9.48 & 11.37 \\
\hline 18 & 13.93 & 14.25 & 14.39 & 14.19 & 10.01 & 9.81 & 11.51 & 10.44 \\
\hline 22 & 14.52 & 13.72 & 14.16 & 14.13 & 13.75 & 11.24 & 12.68 & 12.56 \\
\hline Mean & 14.05 & 13.79 & 14.46 & 14.10 & 12.59 & 10.56 & 11.22 & 11.46 \\
\hline
\end{tabular}

L.S.D at 0.05 level for:

$\begin{array}{lll}\text { Number of irrigation (A) } & \text { N.S } & \text { N.S } \\ \text { Cane varieties (B) } & \text { N.S } & \text { N.S } \\ \text { (A) } \times(B) & \text { N.S } & \text { N.S }\end{array}$

\section{Cane yield:}

Data in Table 8 revealed that applying 22 irrigations to sugarcane increased cane yield by 11.809 and 5.388 tons/fed, in the $1^{\text {st }}$ season, corresponding to 12.423 and 8.939 tons/fed, in the $2^{\text {nd }}$ one, compensate with 14 and/or 18 irrigations, respectively. These results are probably due to the increase in the number of millable canes $/ \mathrm{m}^{2}$ (Table 2) and millable cane height (Table 3 ) accompanying the increase in irrigations from 14 to 18 and 22 irrigations. These results are in harmony with those mentioned by Shahin et al. (1989) and Maher (2003).

Table 9. Effect of number of irrigations on cane yield (ton/fed) of the three sugarcane varieties in $2007 / 2008$ and $2009 / 2010$ seasons.

\begin{tabular}{|c|c|c|c|c|c|c|c|c|}
\hline \multirow{2}{*}{$\begin{array}{l}\text { Variety } \\
\text { Irrigatio } \\
\text { n No. }\end{array}$} & \multicolumn{4}{|c|}{$2008 / 2009$ season } & \multicolumn{4}{|c|}{ 2009/2010 season } \\
\hline & G.T.54-9 & F.160 & Phil.8013 & Mean & G.T.54-9 & F.160 & Phil.8013 & Mean \\
\hline 14 & 37.704 & 37.113 & 43.283 & 39.366 & 34.214 & 31.483 & 33.367 & 33.021 \\
\hline 18 & 46.746 & 42.323 & 48.293 & 45.787 & 40.933 & 33.583 & 35.000 & 36.505 \\
\hline 22 & 51.836 & 50.376 & 51.312 & 51.175 & 45.700 & 41.200 & 49.433 & 45.444 \\
\hline Mean & 45.429 & 43.271 & 47.629 & 45.443 & 40.282 & 35.422 & 39.267 & 38.323 \\
\hline
\end{tabular}

L.S.D at 0.05 level for:

Number of irrigation $(A)$

$\begin{array}{ll}3.446 & 1.050 \\ \text { N.S } & 3.269 \\ \text { N.S } & 5.663\end{array}$

Cane varieties (B)

N.S

5.663

Results pointed out that the tested varieties differed significantly with respect to cane yield/fed in the $2^{\text {nd }}$ season only. Meantime, the differences between G.T. 54-9 and Phil.8013 were too small to reach the level of significance. However, F.160 variety exhibited the lowest cane yield compared to the other two varieties, in both seasons. Similar findings were reviewed by Azzazy, et al. (2005) and Ahmed, et al. (2011). 
Data in the same Table pointed out that cane yield was significantly affected by the interaction between irrigations $x$ sugarcane varieties in the $2^{\text {nd }}$ season. Sugarcane G.T. 54-9 and Phil.8013 varieties varied significantly in cane yield in case of applying 18 irrigations. However, the difference between the two varieties was insignificant by applying 14 irrigations only.

\section{Irrigation intervals and the amount of the applied water:}

Data in Table 1 show that sugarcane grown under conditions of the present work was given 14, 18, and 22 irrigations at an average intervals of 22, 17 and 14 days.

Supplying sugarcane with 14 irrigations saved 1556 and $2846 \mathrm{~m}^{3}$ water, in the $1^{\text {st }}$ season, corresponds to 1511 and $2357 \mathrm{~m}^{3}$, in the $2^{\text {nd }}$ one, compared with 18 and 22 irrigations, respectively. However, a practical point of view showed that 5.388 and 11.809 tons of canes, in the $1^{\text {st }}$ season, and 8.939 and 12.423 tons of canes were obtained, in the $2^{\text {nd }}$ one, by applying 18 and 22 irrigations compared with 14 , successively. Similar trend was observed in respect to sugar yield.

\section{Sugar yield:}

Data in Table 9 indicated that using 22 irrigations revealed an appreciable increase in sugar yield amounted to 1.797 and 0.697 tons/fed, in the $1^{\text {st }}$ season, corresponds to 1.899 and 1.825 tons/fed in the $2^{\text {nd }}$ ones, as compared with that irrigated 14 and/or 18 times, respectively. These results are probably attributed to the increase in cane yield/fed and sugar recovery as mentioned before. These results are in harmony with those reviewed by Shahin et al. (1989) and Maher (2003).

Table 9. Effect of number of irrigations on sugar yield (ton/fed) of the three sugarcane varieties in 2006/2007 and 2007/2008 seasons.

\begin{tabular}{|c|c|c|c|c|c|c|c|c|}
\hline \multirow{2}{*}{$\begin{array}{l}\text { Variety } \\
\text { Irrigatio } \\
\text { n No. }\end{array}$} & \multicolumn{4}{|c|}{$2008 / 2009$ season } & \multicolumn{3}{|c|}{$2009 / 2010$ season } \\
\cline { 2 - 9 } & G.T.54-9 & F.160 & Phil.8013 & Mean & G.T.54-9 & F.160 & Phil.8013 & Mean \\
\hline 14 & 5.315 & 4.816 & 6.345 & 5.492 & 4.834 & 3.340 & 3.153 & 3.776 \\
\hline 18 & 6.513 & 6.207 & 7.055 & 6.592 & 4.242 & 3.278 & 4.031 & 3.850 \\
\hline 22 & 7.490 & 7.110 & 7.268 & 7.289 & 6.254 & 4.596 & 6.175 & 5.675 \\
\hline Mean & 6.439 & 6.044 & 6.889 & 6.458 & 5.110 & 3.738 & 4.453 & 4.434 \\
\hline
\end{tabular}

L.S.D at 0.05 level for:

Number of irrigation (A)

Cane varieties $(B)$

(A) $\times(B)$

0.34
0.712
N.S

0.750

0.866

N.S 
The evaluated varieties varied significantly in sugar yield/fed in the $1^{\text {st }}$ and $2^{\text {nd }}$ seasons. Meanwhile, G.T.54-9 and Phil.8013 varieties replaced the $1^{\text {st }}$ order in sugar production (without significant difference) in both season. Moreover, the lowest sugar yield/fed was recorded by F.160 variety. These results were actually due to the same trend of the tested varieties with respect to their cane yield, where it is well known that sugar yield is principally dependent on both cane yield and sucrose percentage. Similar results had been showed by Azzazy, et al. (2005) and Ahmed et al. (2011) who recorded differences among the tested sugarcane varieties with regard to sugar yield.

Results in the same Table pointed out that the interaction between number of irrigations and cane varieties had insignificant effect on sugar yield in both season.

It could be concluded that under the conditions of the present work, growing either G.T.54-9 or Phil.8013 with the application of 22 irrigations can be recommended to obtain the highest cane and sugar yields/fed.

\section{REFERENCES}

1. Ahmed Z.A. and A.M.A. El-Shafai. 2007. Yield and quality of two sugarcane varieties as affected by bio and inorganic nitrogen fertilization. J. Agric. Sci. Mansoura Univ, 32 (1): 61-76.

2. Ahmed, Z. A., A. M. Ahmed and M. S. H. Osman. 2011. Optimum inter-row spacing and number of ploughings for two promising sugarcane varieties. Egypt. J. Agric. Res., 89 (1): 301-315.

3. Anonymous. 1981. Chemical Control Lab., the Egyptian Co. for Sugar and Integrated Industries. Jan., P. 232.

4. O. A. C. 1995. Association of Official Analytical Chemists. Official methods of analysis, 16th Ed., A.O.A.C. International, Washington, D.C., USA.

5. Azzazy, N.B., A.M.A. El-Shafai and A.M. Abd El-Aal. 2005. Performance of some promising plant and ratoon sugarcane varieties under different nitrogen levels. Egypt. J. Agric. Sci., 20(8A):65-78.

6. El-Shafai, A.M.A. 1996. Water requirement of sugarcane under different levels of nitrogen fertilization. Ph.D.Thesis, Agron.Dept. Fac.Agric., Moshtohor, Zagazig Univ., Egypt.

7. El-Sogheir, K.S. and A. I. Abd El-Fattah. 2009. Evaluation productivity and susceptibility of some promising sugarcane varieties to some plant diseases and nematode under different row spacing. J. Biol. Chem. Enviro. Sci., 4 (1): 285-318.

8. Humbert, R.P. 1968. The growing of sugarcane.(Book) Elsevier Publ. Co., 
Amesterdam.

9. Ismail, A.M.A., M.A. Bekheet and A.S. Abo El-Hamd. 2008. Yield and quality of four sugarcane varieties as influensed by seed rate and nitrogen fertilization. Egypt. J. Appl. Sci., 23(1):107-123.

10. Mohamed, Kh. El., A.M., Elwan and Tawfik, Sahar F. 2012. The effect of cultivar and harvest time on yield and quality of sugar cane. Minia J. Agric. Res. \& Develop., 32 (5) : 35-48.

11. Maher, M.M.I. 2003. Evaluation of some sugarcane varieties under different irrigation treatments. Ph.D. Thesis, Agron. Dept. Fac. Agric., Minia Univ., Egypt.

12. Said Rahman, S.G., K.A. Mahmood, K. Inayafallah, S. Rahman and I. Khan. 1991. Screening of sugar varieties drought resistance, yield and quality characters. Sharad. J. Agric., 7 (1): 59-64.

13. Shahin, M.M., Tawadros H.W., Mosa E.M. and E. G. Morkos. 1989. Number of irrigation and evapotranslation in relation to crop sugar yield and juice characteristics for sugarcane. J. Agric. Sci., Mansoura Univ.,14 (3), 1972-1980

14. Snedecor, G.W. and W.G. Cochran. 1981. Statistical methods. Seventh Ed. Iowa State Univ.Press, Ames, Iowa, USA.

15. Van Dillewijn, C. 1952. Botany of sugarcane. Chronica Botanica Co.: (Book) Dept., Waltham, MA. USA.

16. Yadav, R.L. and R.K. Sharma. 1980. Effect of nitrogen level and harvesting date on quality characteristics and yield of four sugarcane genotypes. Indian J. Agric. Sci., 50: 581-589. 


\title{
تقييم ثلاثة أصناف قصب سكر منزرعة تحت عدد من مرات الري
}

\author{
أحمد زكى أحمد ، عبد الله محد احمد و كمال سبا الصغير \\ معهز بحوث المحاصيل السكرية - مركز البحوث الزراعية - الجيزة - مصر
}

أقيمت هذه الدر اسة فى محطة البحوث الزر اعية بالمطاعنة - محافظة الأقصر (خط عرض

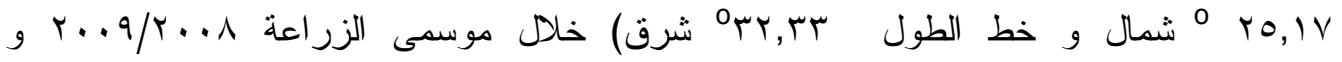

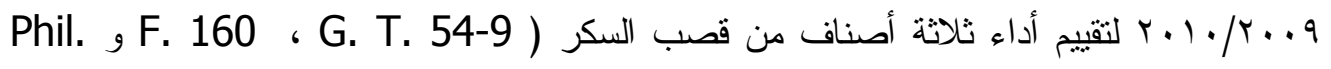

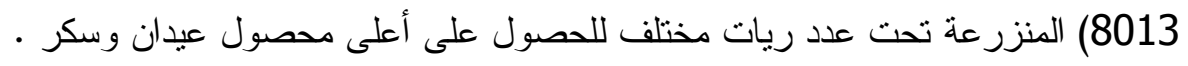

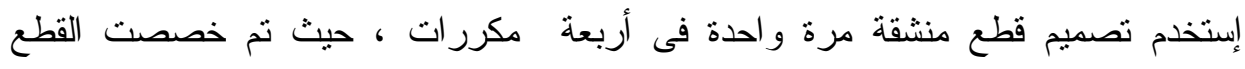

الرئيسية لعدد الريات فى حين وزعت أصناف قصب السكر فى القطع الثقية .

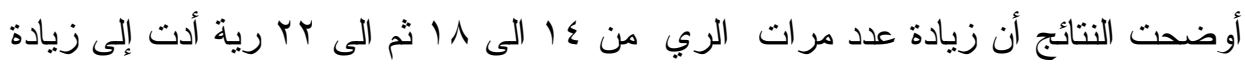

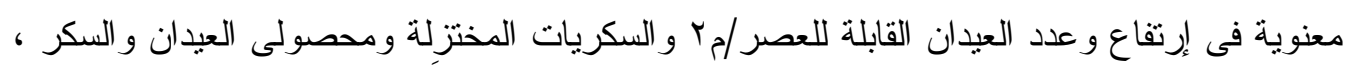

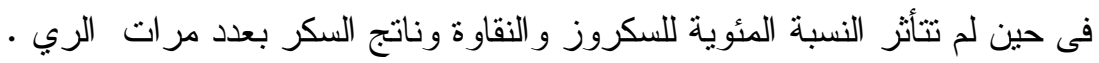

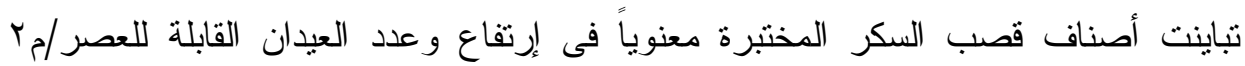

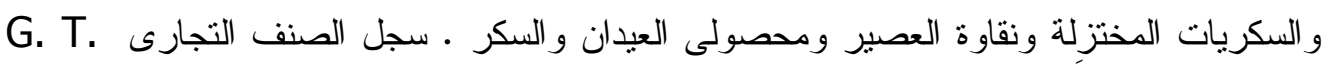

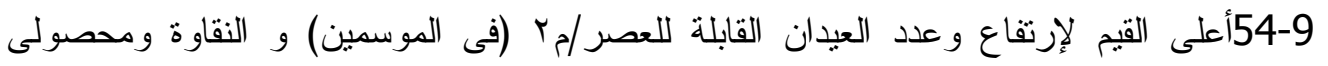
العيدان و السكر (فى الموسم الثانى) ، بينما أعطى الصنف 8013 Phil.

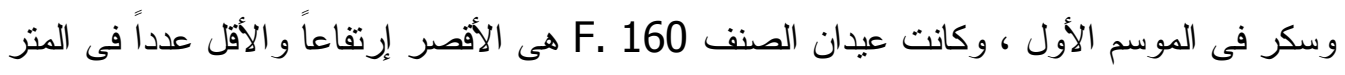
المربع ، كما سجل هذا الصنف أقل القيم لنقاوة العصير ومحصولى العيدان و السكر ، ولكنه سجل أعلى نسبة مئوية للسكريات المختزلة مقارنة بالصنفين الآخرين •

تحت منل ظروف هذا البحث ، يمكن التوصية بزر اعة أي من الصنفين 8013 و Phil.

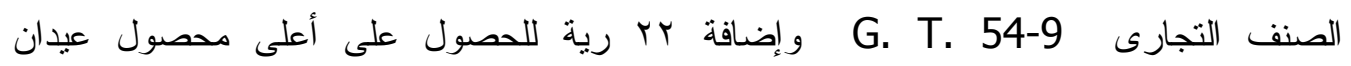
وسكر /فدان. 